\title{
SOYBEAN SEED QUALITY AS AFFECTED BY TIME OF PLANTING IN THE DRY ZONE OF SRI LANKA*
}

\author{
V. ARULNANDHY \\ Department of Agriculture, Peradeniya, Sri Lanka
}

\begin{abstract}
AND
Y.D.A. SENANAYAKE

Postgraduate Institute of Agriculture, University of Peradeniya, Peradeniya, Sri Lanka.

(Date of receipt : 19 May 1987)

(Date of acceptance : 14 September 1987)

Abstract : Eight soybean (Glycine max (L.) Merr.) cultivars were planted during the first week of each calender month in the dry zone of Sri Lanka. The soybean crops established from May and June plantings produced yield and size of seed significantly greater than the other plantings. These seeds, which matured under more favourable weather conditions with the combination of daily mean temperature $\left(28^{\circ} \mathrm{F}\right)$ and daily maximum relative humidity $(75 \%)$, were of the highest quality as indicated by their high level of viability and vigour. In contrast, the crop of January and February plantings gave seeds of lowest quality and at the time of their maturation the daily mean temperature was remarkably high $\left(30-31^{\circ} \mathrm{C}\right)$. The predicted model explaining the effect of weather factors on seed quality reveals that daily mean temperature and daily maximum relative humidity are the significant attributes to seed quality of soybean.
\end{abstract}

\section{Introduction}

Weather is probably the preharvest factor that has the greatest influence on seed quality in many crops, including cereals and legumes. Marked weather injuries in wheat seeds have been attributed to results from temperature ${ }^{12}$ or preharvest rains. ${ }^{11}$ Exposure to dampness ${ }^{6}$ or hot weather 9 during maturation could lead to the production of low quality seeds in soybean.

There are distinct advantages in producing soybean seeds under favourable weather conditions and such conditions are rather uncommon in the subtropics and tropics. ${ }^{1}$. Under favourable conditions, seed set and recovery is usually optimum; there is low incidence and severity of pests and diseases and germination and seed vigour are quite high. Hence, seed quality is usually good if seeds are produced under favourable conditions. In soybean growing areas of Sri Lanka, the prevailing practice has been to plant soybean in the early part of May and November which are the beginning of dry and wet seasons, respectively. However, it could be possible to extend the * Part of Ph.D. thesis submitted by senior author, to the Postgradurate Institute of Agriculture of the University of Peradeniya, Sri Lanka. 
planting time within these growing seasons. This is important for various reasons which include unavailability of seed material and labour at the peak time of seasons and crop failure due to uncertain weather. Therefore, an investigation was undertaken to determine the most appropriate time of planting for quality seed production in soybean in the dry zone of Sri Lanka. This investigation also attempts to critically analyse the major weather factors that are responsible for seed quality of soybean.

\section{Experimental}

The experiment consisted of eight soybean cultivars (Bossier, Improved Pelican, M 534, Pb-1, PM 78-13, PM 78-25, UPSL 216, 30120-49-3) arranged in a randomized complete block design with four replications. The block was $27.5 \mathrm{~m} \times 1.6 \mathrm{~m}$ in size and consisted of eight plots. Each plot had four $3 \mathrm{~m}$ rows spaced at $40 \mathrm{~cm}$, having plants at $5 \mathrm{~cm}$ apart. The seeds of these cultivars were planted on the fifth day of each month for 12 months (May 1984 to April 1985) at the Agricultural Research Station, Maha Illuppallama, which is situated in the dry zone of Sri Lanka. Maha Illuppallama, being at a latitude of $8^{\circ} 5^{\prime} \mathrm{N}$, could be classified as a humid tropical area. The experiment was well managed by providing the optimum conditions for growth and development. Seeds were harvested from two centre rows of each plot after $3-3 \frac{1}{2}$ months, at development stage $R_{8}$ at which $95 \%$ of the pods were mature. ${ }^{8}$ Harvested seeds were sun-dried to a seed moisture content of $10 \%$ and stored under cold storage at $10^{\circ} \mathrm{C}$ and $45 \%$ relative humidity until assayed for viability and vigour. The seed yield and the weight of 100 seeds were also recorded.

From seed lots produced by each planting date, 25 seeds from each cultivar and each replicate were drawn at random for testing of seed quality. These seeds were mixed with Captan $80 \%$ WP (N[(Trichloromethyl) thio] 4-cyclohexane 1,2 dicarboximide) at $3 \mathrm{~g} / 1 \mathrm{~kg}$ of seeds and planted in moist sterilized sand contained in plastic boxes. Seeds were germinated under illumination at $8 \mathrm{~h}$ a day, using flourescent lamps of 750-1000 lux placed $1 \mathrm{~m}$ above the sand boxes, and at a constant temperature of $30 \pm 1^{\circ} \mathrm{C}$, the known approximate optimum for soybean seed germination. ${ }^{5}$ Another 25 Captan-treated seeds of each sample were planted in the field where conditions were favourable for germination.

Seedlings that emerged were counted five and eight days after planting in both germination tests. Seedlings were carefully uprooted eight days after planting, examined and classified in accordance with the criteria of the Association of Official Seed Analysts. ${ }^{2}$ Seedling length and dry weight were determined using five seedlings taken at random from each sample. Seedling length was measured from the point of attachment of the cotyledons to the 
root tip. The same seedlings were used to obtain the dry weight gravimetrically after drying in an oven at $60^{\circ} \mathrm{C}$ for $48 \mathrm{~h}$.

Percentage germination was used as a measure of seed viability. Reported germination values include only normal seedlings counted after eight days. The seedling length and dry weight were the parameters assigned to estimate seed vigour. In addition, the emergence rate was computed as a modification of the method suggested by Maguire ${ }^{10}$ using the formula given below:

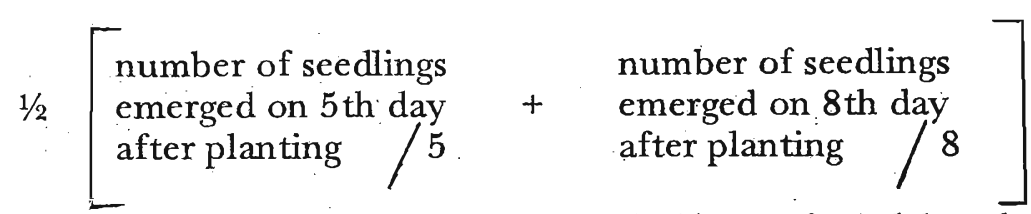

The data obtained on viability and vigour of seed lots harvested at different times were processed and subjected to the standard analysis of variance. Germination percentages were transformed to arcsine degree scale before statistical analysis. Means were compared using Duncan's Multiple Range Test: ${ }^{7}$ Correlations were carried out to see whether seed yield could be considered as a guide to predict seed quality. Regressions were computed as appropriate.

\section{Results and Discussion}

Results indicate a considerable variation in yield, size and quality of seeds produced from soybean crops that were established from different planting dates. The mean germination of seed lots of eight cultivars in sand was over $91.8 \%$ for the plantings of May, June and July. These values were significantly higher than \% germination of seed lots from other plantings, except for the August and November plantings (Table 1). Likewise, the field germination of seeds produced from the plantings of May, June and July was over $89.8 \%$ and significantly higher than the other plantings, with the exception of August planting (Table 1). The \% germination of January and February plantings was lowest in sand germination test ${ }^{9}$ while field germination test showed lowest germination in February and March plantings. These results showed that seeds produced from field plantings made during the period May to July were generally of high viability.

Emergence rates higher than 3.0 per day were noticed in the plantings made from May to August and also in November in both sand and field germination and these values did not differ significantly from each other (Table 1). Lowest values for emergence rate were obtained for the plantings of January, February and March. 


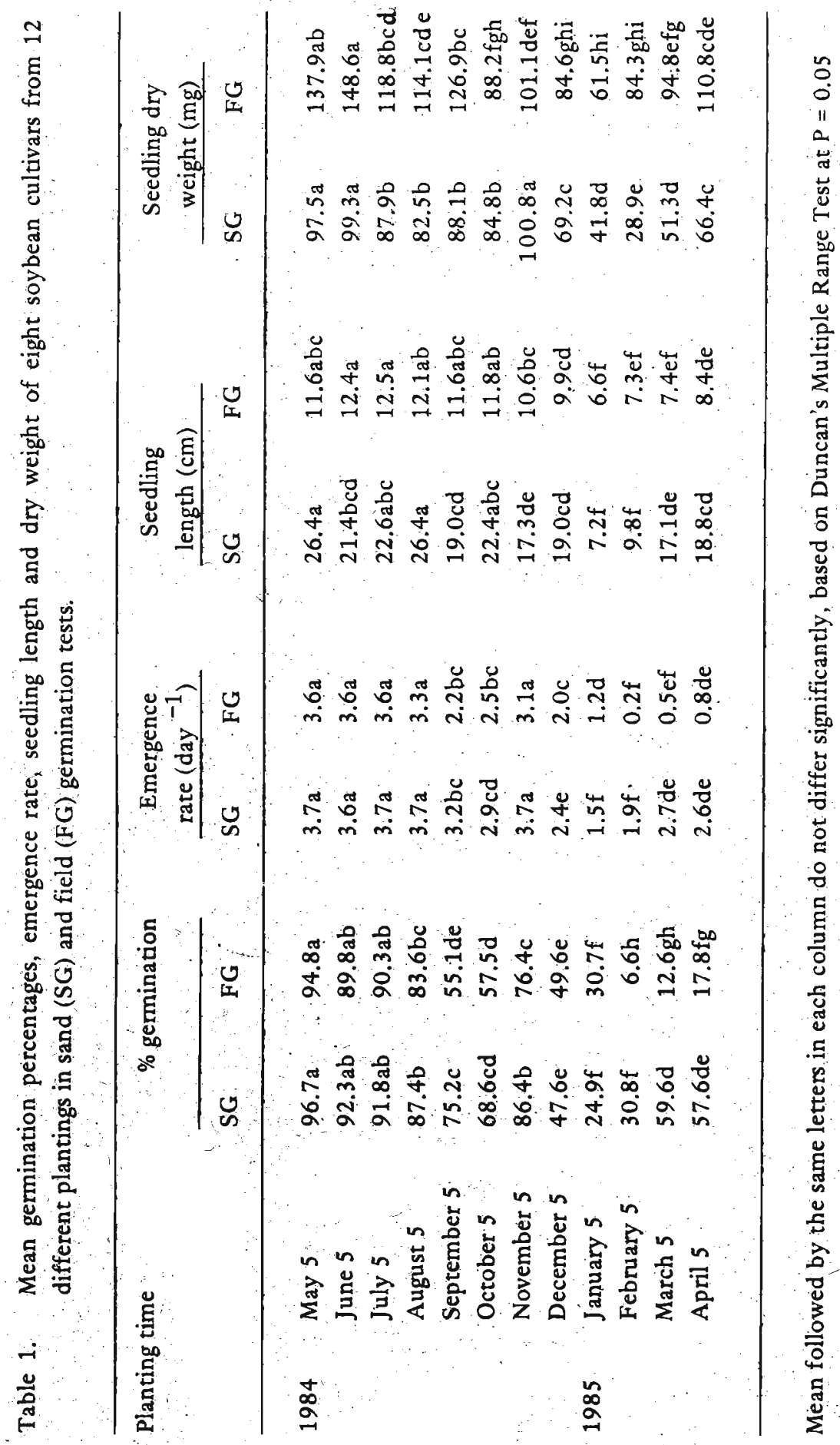


The highest mean seedling length was recorded for May and August plantings in sand germination. In field germination, maximum length was observed from July planting; however, it did not differ statistically from May and June plantings(Table 1). The highest mean seedling dry weight was for the November planting in sand germination which however, did not show any significant difference from plantings made in May and June (Table 1). With respect to seedling dry weight under field conditions, May and June plantings showed the highest weight. The above data generally suggest that the seeds produced from plantings made during the period May to July and also in November have good seed vigour.

Table 2. Mean seed yield and size of eight soybean cultivars harvested from 12 different plantings in one year.

\begin{tabular}{|c|c|c|c|}
\hline \multicolumn{2}{|c|}{ Planting time. } & \multirow{2}{*}{$\begin{array}{l}\quad \text { Mean } \\
\text { seed yield } \\
(\mathrm{Kg} / \mathrm{ha})\end{array}$} & \multirow{2}{*}{$\begin{array}{l}\text { Mean } \\
\text { seed size } \\
\text { (g/100 seeds) }\end{array}$} \\
\hline Year & Date & & \\
\hline \multirow{9}{*}{19.84} & & & 154 \\
\hline & June 5 & $4042.3 \mathrm{a}$ & $15.4 \mathrm{a}$ \\
\hline & July 5 & $4 / 05.12$ & $15.2 \mathrm{a}$ \\
\hline & $\begin{array}{l}\text { July } 5 \\
\text { August } 5\end{array}$ & $3028.9 \mathrm{~b}$ & $12.6 \mathrm{~b}$ \\
\hline & $\begin{array}{l}\text { August } 5 \\
\text { September } 5\end{array}$ & $2255.4 \mathrm{~d}$ & $12.6 \mathrm{~b}$ \\
\hline & & $843.4 \mathrm{~h}$ & $11.1 \mathrm{bc}$ \\
\hline & $\begin{array}{l}\text { October } 5 \\
\text { November } 5\end{array}$ & $1301.9 \mathrm{f}$ & $11.8 \mathrm{bc}$ \\
\hline & & $2882.6 c$ & $13.3 \mathrm{~b}$ \\
\hline & December $\mathbf{5}$ & $1120.0 \mathrm{~g}$ & $11.1 \mathrm{c}$ \\
\hline \multirow[t]{5}{*}{1985} & January 5 & & \\
\hline & February 5 & $684.6 \mathrm{i}$ & $11.6 \mathrm{bc}$ \\
\hline & & $486.6 \mathrm{j}$ & $6.4 d$ \\
\hline & April 5 & $1547.7 \mathrm{e}$ & $11.8 \mathrm{bc}$ \\
\hline & & $2249.4 d$ & $12.9 \mathrm{~b}$ \\
\hline
\end{tabular}

Mean followed by same letters in each column do not differ significantly at $P=0.05$ based on Duncan's Multiple Range Test. 
The highest seed yield was also obtained from May and June plantings which had the highest seed size as well (Table 2). Seed yield and seed size of these plantings were found to be significantly greater than those of other plantings, including November planting which is the regular planting time during the wet season. Considering the collective data on seed yield, seed size, seed viability and vigour together, the best time of planting for seed production appears to be the period during May to June. in the dry zone of Sri Lanka. High quality seeds that were produced from May and June plantings matured under more favourable weather conditions with the combination of daily mean temperature of about $28^{\circ} \mathrm{C}$ and daily maximum relative humidity of $75-78 \%$ (Table 3 ). In contrast, seeds of plantings in January and February which were of lowest quality (Table 1), matured when the daily mean temperature was highest $\left(30-31^{\circ} \mathrm{C}\right)$. Several workers have pointed out earlier that adverse weather conditions during seed maturation could cause severe seed quality problems which reduce seed viability and vigour in soybean. ${ }^{3,4,6,11}$ Gregg $^{9}$ reported that dry hot weather and inadequate soil moisture during seed maturation resulted in green seeds of soybean which were of low quality with respect to germability.

Table 3. Mean temperature and maximum relative humidity during seed maturation of the soybean cultivars planted at 12 different planting times of the year.

\begin{tabular}{|c|c|c|c|}
\hline \multicolumn{2}{|c|}{ Planting time } & \multirow{2}{*}{$\begin{array}{l}\text { Mean temperature } \\
\quad\left({ }^{\circ} \mathrm{C}\right)\end{array}$} & \multirow{2}{*}{$\begin{array}{c}\text { Maximum relative } \\
\text { humidity (\%) }\end{array}$} \\
\hline Year & Date & & \\
\hline \multirow[t]{8}{*}{1984} & May 5 & 28.2 & 78.4 \\
\hline & June 5 & 28.4 & 74.9 \\
\hline & July 5 : & 26.8 & 89.6 \\
\hline & August 5 & 27.2 & 82.6 \\
\hline & September 5 & 24.8 & 90.9 \\
\hline & October 5 & 25.9 & 92.7 \\
\hline & November 5 & 25.9 & 91.7 \\
\hline & December 5 & 27.2 & 88.0 \\
\hline \multirow[t]{4}{*}{1985} & January 5 & 30.0 & 80.1 \\
\hline & February 5 & 31.0 & 75.5 \\
\hline & March 5 & 28.3 & 82.1 \\
\hline & April 5 & 28.4 & 83.6 \\
\hline
\end{tabular}


Seed yield was significantly and positively correlated with germination, emergence rate, seedling length and dry weight (Table 4). The close association of seed yield with seed quality characteristics such as seed viability and vigour suggests that seed yield may be considered as a useful guide to predict seed quality.

Table 4." Correlation between seed yield and parameters of viability and vigour of seeds of different plantings.

Correlated characters

Correlation coefficient

Seed yield

(486.6 - 4842.5 Kg/ha)

Vs

Germination

$(23.3-97.4 \%)$

$0.7649^{++}$

Emergence rate

$\left(1.46-3.70 \mathrm{day}^{-1}\right)$

$0.6223^{++}$

Seedling length

$(7.2-26.4 \mathrm{~cm})$

$0.6904^{++}$

Seedling dry weight

(28.9 - $100.8 \mathrm{mg})$

$0.7263^{++}$

${ }^{++}$Significant at $\mathrm{P}=0.01$

A multiple linear regression model was used to estimate the effect of weather parameters that prevailed during the period from physiological to harvest maturity on seed quality (Y) in terms of seed viability (\% germination in sand at $30^{\circ} \mathrm{C}$ and field) and vigour (emergence rate) (Table 5). The weather parameters included in the estimation were daily maximum relative humidity (XI), daily minimum relative humidity (X2), daily mean relative humidity (X3), daily mean temperature (X4), daily rainfall (X5) and daily sunshine hours (X6). From the available data, the predicted model by estimation is given as:

$$
\mathrm{Y}=\mathrm{B}_{\mathrm{o}}-\mathrm{B}_{1} \mathrm{X}_{1}-\mathrm{B}_{2} \mathrm{X}_{2}+\mathrm{B}_{3} \mathrm{X}_{3}-\mathrm{B}_{4} \mathrm{X}_{4}+\mathrm{B}_{5} \mathrm{X}_{5}+\mathrm{B}_{6} \mathrm{X}_{6} \text {. }
$$


Table 5. Estimates of the coefficients of regressions for variables in the model for determining the effect of weather parameters, during the period from physiological to harvest maturity (seed maturation), on seed quality.

\begin{tabular}{|c|c|c|c|}
\hline Variable & $\begin{array}{l}\% \text { germination } \\
\text { in sand at } \\
30^{\circ} \mathrm{C}\end{array}$ & $\begin{array}{l}\% \text { germination } \\
\text { in field }\end{array}$ & $\begin{array}{l}\text { Emergence } \\
\text { rate in sand } \\
\text { at } 30^{\circ} \mathrm{C}\end{array}$ \\
\hline Intercept & 299.9035 & 61.3811 & 10.1062 \\
\hline $\begin{array}{l}\text { Daily maximum RH (\%) } \\
\qquad(\mathrm{X} 1)\end{array}$ & $\begin{array}{l}-1.4968^{++} \\
(0.4366)\end{array}$ & $\begin{array}{l}-1.0305^{+} \\
(0.5726)\end{array}$ & $\begin{array}{l}-0.0442^{++} \\
(0.0134)\end{array}$ \\
\hline $\begin{array}{l}\text { Daily minimum RH (\%) } \\
\text { (X2) }\end{array}$ & $\begin{array}{c}-0.1473 \\
(0.3370)\end{array}$ & $\begin{array}{l}-0.8422 \\
(0.4944)\end{array}$ & $\begin{array}{l}-0.0036 \\
(0.0116)\end{array}$ \\
\hline $\begin{array}{l}\text { Daily mean } \mathrm{RH}(\%) \\
(\mathrm{X} 3)\end{array}$ & $\begin{array}{c}0.9721 \\
(0.6878)\end{array}$ & $\begin{array}{c}1.0892 \\
(0.9020)\end{array}$ & $\begin{array}{c}0.0307 \\
(0.0212)\end{array}$ \\
\hline $\begin{array}{l}\text { Daily mean temperature }\left(8^{\circ} \mathrm{C}\right) \\
(\mathrm{X} 4)\end{array}$ & $\begin{array}{c}-6.1626^{+++} \\
(0.9993)\end{array}$ & $\begin{array}{l}-7.1747^{+++} \\
(1.3105)\end{array}$ & $\begin{array}{l}-0.2016^{+++} \\
(0.0307)\end{array}$ \\
\hline $\begin{array}{l}\text { Daily rainfall (mm) } \\
\text { (X5) }\end{array}$ & $\begin{array}{r}0.2513 \\
(0.1626)\end{array}$ & $\begin{array}{c}0.2568 \\
(0.1739)\end{array}$ & $\begin{array}{r}0.0078 \\
(0.0061)\end{array}$ \\
\hline $\begin{array}{l}\text { Daily sunshine hours } \\
\text { (X6) }\end{array}$ & $\begin{array}{c}0.3303 \\
(0.6181)\end{array}$ & $\begin{array}{r}0.6972 \\
(0.8113)\end{array}$ & $\begin{array}{c}0.0151 \\
(0.0191)\end{array}$ \\
\hline Coefficient of correlation ( $r$ ) & 0.4434 & 0.3724 & 0.4742 \\
\hline
\end{tabular}

,,+++++ Significant at $\mathrm{P}=0.05,0.01,0.001$, respectively.

Standard error of estimates are given in parenthesis under coefficient of regression values.

The model indicates that daily mean temperature and daily maximum relative humidity had a significant influence on seed viability and vigour. The other parameters considered did not influence seed quality significantly (Table 5). The regression coefficient values predict that $\%$ germination in sand and field respectively decrease by 6.1626 and 7.1747 for each $O C$ increase in daily mean temperature and 1.4968 and 1.0305 for each \% increase in daily maximum relative humidity (Table 5). Emergence rate which measures seed vigour declines by 0.0442 and 0.2016 per day for each 
$\%$ increase in daily maximum relative humidity and each ${ }^{\circ} \mathrm{C}$ increase in daily mean temperature (Table 5). The data obtained reveal that daily mean temperature and daily maximum relative humidity during the period from physiological to harvest maturity of soybean crop are the most important determinants of seed quality.

\section{Conclusions}

Collective data on yield, size, viability and vigour of seeds produced from different plantings suggest that the best time of planting for the production of maximum yield of high quality soybean seed in the dry zone of Sri Lanka would be during the period of May to June when moderate daily mean temperature $\left(28^{\circ} \mathrm{C}\right)$ and daily maximum relative humidity $(75 \%)$ prevail during seed maturation. In contrast, seeds from January and February plantings which mature under high daily mean temperature $\left(30-31^{\circ} \mathrm{C}\right)$ would be of lower quality. The data also show that, of the weather factors, daily mean temperature and daily maximum relative humidity during seed maturation are the probable major determinants of soybean seed quality.

\section{Acknowledgements}

The authors are grateful to the Department of Agriculture, Sri Lanka, for providing funds to carry out the present study.

\section{References}

1. ANDREWS, C.H. (1982) In Soybean Seed Quality and Stand Establisbment; Proceedings of a Conference for Scientists of Asia 25-31 January 1981. pp. 19-25. Illinois, Univ. of Illinois, INTSOY Series No. 22.

2. Association of Official Seed Analysts. (1972) Proc. Assoc. Off. Seed Anal. 60: $1-116$.

3; BURDETT, R.A. (1977) Effect of Weather on Soybean (Glycine Max (L.) Merr.) Seed Quality. Ph. D. Dissertation, Mississippi Stat. Univ., Mississippi Stat.

4. CostA, A.V. (1979) An. I. Semin. Nac. Pesq. Soja 2: 193-308.

5. DELOUCHE, J.C. (1952). Proc. Assoc. Off. Seed Anal. 43: 117-126.

6. DELOUCHE, J.C. (1974) In Soybean Production, Marketing and Use. pp. 42-62. Tenn. Val. Autb. Bull. Y-69. 
7. DUNCAN, D.E. (1955) Biometrics 11: 1-42.

8. FEHR, W.R., CAVINESS, C.E., BURMOOD, D.T. \& PENNINGTON, J.S. (1971) Crop Sci. 9: 929-931.

9. GREGG, B.R. (1982) In Soybean Seed Quality and Stand Establishment; Proceedings of a Conference for Scientists of Asia 25-31 January 1981. pp. 52-56. Illinois, INTSOY Series No. 22.

10. MAGUIRE, J.O. (1962) Crop Sci. 2: 176-177.

11. MORSE, W.J., CARTER, J.L: \& HARTWIG, E.C. (1950) USDA Farmer's Bull. 2023: $15-16$.

12. RIDDETT, J.A. \& GRIES, G.A. (1956) Indiana Aca. Sci. Proc. 66: 52. 